\title{
The Service Pattern in the Shinjo Basin, Yamagata Pref.
}

A Research at a Less Populated Basin in Japan-

\section{Yoshio Wat ANABE}

\section{Introduction}

Most of the larger basins in Japan have their wide bottoms dominant of paddy agriculture with their heavy population density. However, the Basin of Shinjo, a so-called typical retarded area in Japan, has a less population in correlation to its size. This seems to the writer, intermingled with its proper character which musti have a community with the basins Japan has in abundance, to show one type through which some aspects of rural services in Japan may be observed.

As a matter of course, the stress of the analysis is laid on the service pattern under the control of the topography of a basin and on the service capacity as the economics of a nodal region less populated. For both, there is Christaller's work in which he clarified the fundamental principle of central places in relating to the distribution of population. ${ }^{(1)}$ The writer's purpose is not to take up the principle itself again to discuss, but to examine in Japan one type of service out of many systems expected in the principle and to give some possible interpretation about its mechanism which may add something to Christaller's theory.

\section{The Basin Type of Service Pattern}

A basin which can be regarded as a topographical unit, is theoretically assumed to have an influence on the service pattern with the following characteristics $^{(2)}$ : (1) A basin generally has a mountainous zone around, which is less populated, and a great centre can not be developed here. (2) It has a tendency of forming one trade area of its own, because of the direct influence of surrounding mountain ranges on the inter-regional traffics, and because there is no great centre around as the above item shows, and further because

(1) W. Christaller : Die Zentralen Orte in Süddeutschland, Jena 1933

(2) The author intends to consider the matters to be stated in this and next sections, in the near future based on the statistics of the whole Töhoku Region, more precisely.

"The treatises in this report have no relation to it, but a temporary one to interpret the Shinjo Basin. 
it was often occupied in Japan by one clan domain in the feudal days (the Shinjo Basin is one illustration). ${ }^{(3)}$ (3) For this reason, the main centre (one in principle) must be formed in the middle part which is usually the weighing centre of the population. (4) Influenced by this centre, the middle part of the bottom can not admit of larger ones. ${ }^{(t)}$ For the above reasons, an arrangement of concentric circles can be supposed, from the centre of a basin towards its fringe, its structures being-the great centre (the centre of the whole

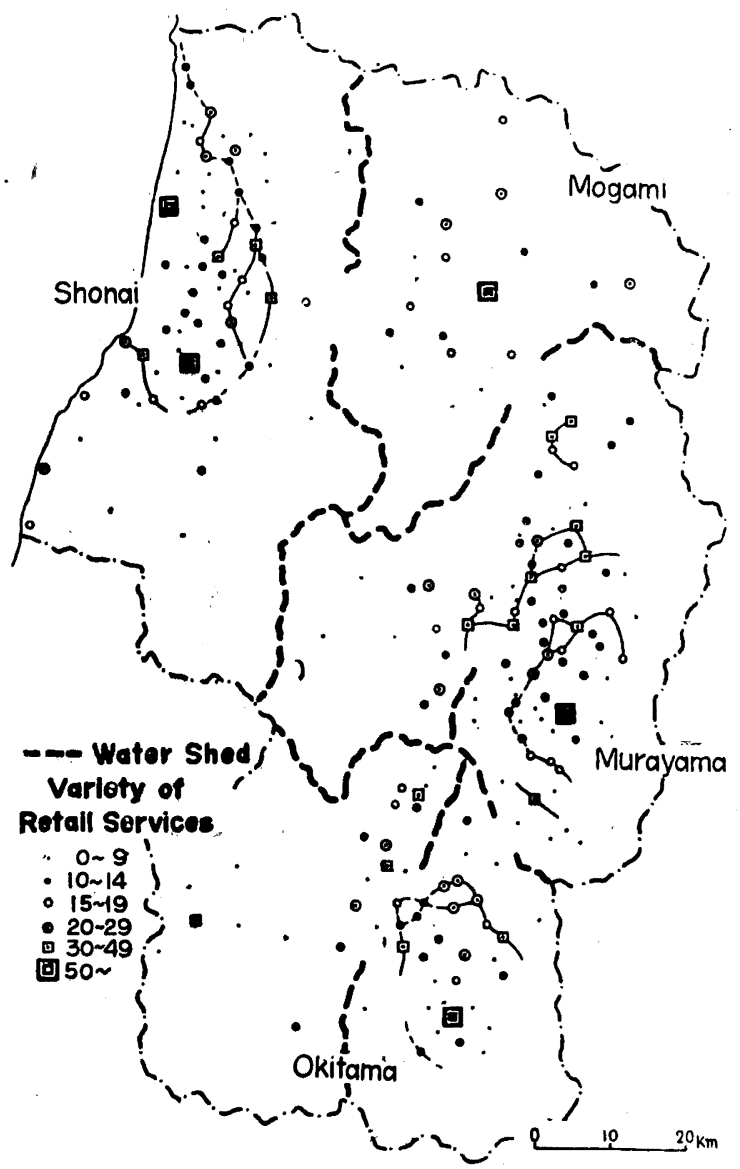

Fig. 1 Distribution of centres according to administrative unit basin) - minor ones (in the vicinity of the great one) -medium ones (being often divided into several layers according to the size of a basin) - minor ones (peripheral mountainous zone). In order to observe the real state of whole Yamagata Pref. the author has made Fig. 1, based on the census data got in 1951 according to administrative units. In the figure, the number of the kinds of commerce (the division consists of 59 ,its items shown in Table I) is taken up as the most simple expression of "facility" of each unit. (This will better indicate the grades of the centre of a respective unit because a kind of commerce almost always appear first not in the tributaries but in the centre. While, the number of shops 'is rather correlated to the total population

(3) Kozo Iwata : Political Geography of National and Clan Boundaries in Japan, Tokyo, 1953. (In Japanese) p.78 and plates

(4) J.H.Kolb \& E.de S.Brunner : A Study of Rural Society, Education Manual 268 for the United States Armed Forces, Copyright 1940 and 1935, p.66,128.

J.E Brush : The Hierachy of Central Places in southwestern Wisconsin, Geogr. Rev. July 1953, pp. $380-402$ 
1

of a unit because a pure rural land within each unit raises many shops of elementary orders.) The lines combined one with another are drawn as the aid of the easy observation of circlings, the valley systems and the means of communication being taken into consideration. In Yamagata pref., the four basins and one coastal plain, are observed to suggest respectively concentric circle structure of its own. Viewed from the pattern, the Yamagata and the Yonezawa Basins have their centres situated eccentrically south and, again, in the case of the West Okitama basin with its half independent centre, Nagai-machi, and the Shinjo Basin with Shinjo-city as its centre, a closer observation is necessary to discern their concentric circle structures, for the low population densities cause too large areas of administrative (also for census data) units.

\section{The Classification of Shops according to Types of Distribution}

- "Group of services according to the grades of urban settlement" as is stated by Dickinson and Smailes, ${ }^{(5)}$ can be expected in Japan as well. Fig. 2-A has been drawn to show a ranking of cities, towns and mura viewed from the number of the kinds of commercial service. $F_{V}$ is of repose character, which is thought to be a kind of "Grade" and to show "rural proper". Ft and Fc show the process of rising higher and in them may perhaps be observed some reposing

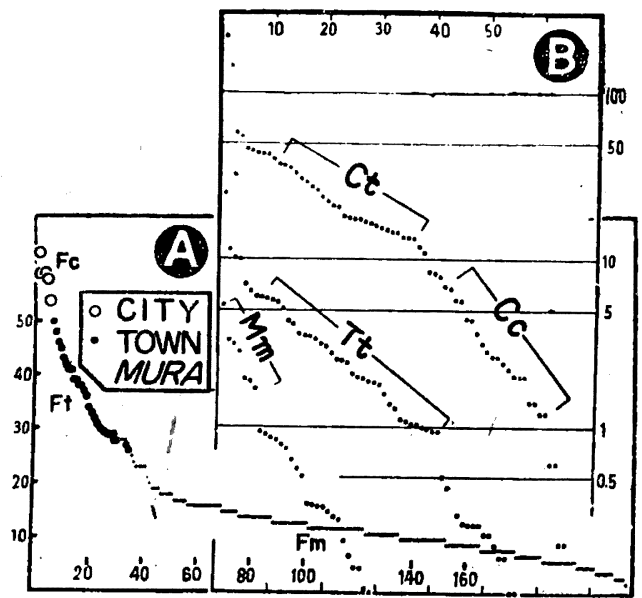

Fig.2 A. Service rank of administrative units according to varieties of commerce

B. Shop-number rank of kinds of commerce, viewed from cities, towns and mura respectively parts of a few steps if they are observed more closely on more collective data. The reposing parts near 25, 40 and 60 shops in the Figure show such a tendency and these suggest the existence of "groups of services". In this figure, signs of cities, towns and mura are also used and these reveals that the difference of these administrative units can be taken up as an emergent indicator of grades of central service. In Fig. 2-B, the number (per city, town and mura) 1 of the shops belonging to each trade is ranked. That of mura indicates that the only

(5) R.E. Dickinson : City Region and Regionalism, London, 1947, p.47 
several kinds $(\mathrm{Mm})$ are in an outstandingly peculiar high level suggesting the kinds common with mura. But in the case of towns, the number abruptly goes down with 1 as its boundary as well, and 40 kinds above the gap are thought to be a "group of services of town" in which some 30 kinds (excluding $\mathrm{Mm}$ ) mean the differentiation of town commerce $(\mathrm{Tt})$. In the case of cities, two parts of discontinuity are observed both near 1 and 15 shops. The former which is an obvious one shows that trade core of a city $(\mathrm{Ct})$ is only a voluminous increase of the same kinds already differentiated in towns. And some twenty (Cc, 1-15 Shops) show the obscure differentiation in cities themselves. The above features are expressed collectively in Fig.3, in which each item of trade is

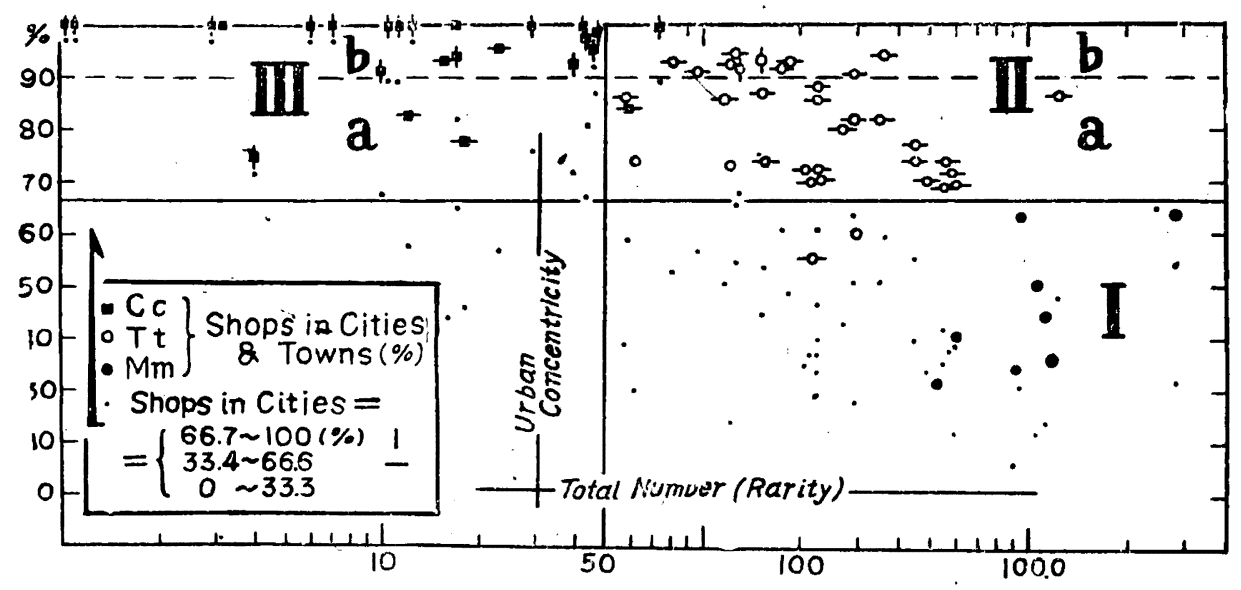

Fig.3 Classification of shops

plotted from both the view-point of rarity (total number of shops) and urban convergency (the percentage of shops in cities and towns). Here the three symbols are used to check the classification in Fig. 2-B and the other two symbols and dots indicate the percentage of shops in cities. Though the number of the shops often amounts to a considerable high one (near to 200 in the whole pref., 15 per city or town), yet the percentage of them still remains low on the rural side, being kept more than two-thirds by cities and towns. (There are 5 cities, 30 towns and 190 mura in the prefecture, the total population being $290,000,280,000$ and 790,000 .) On the contrary a comparatively small number of trade varieties of commoner character suddenly diffuse into mura. Therefore, the group (I) can be distinguished from the others by the one-third-line.

To make a further classification, the writer takes up the line of 50 (1.5 per city or town) shops in rarity (II and III). This seems to be the most suitable division of $\mathrm{Cc}$ and $\mathrm{Tt}$, and may also be a division of "shops of cities". 


\begin{tabular}{|c|c|c|c|c|c|c|}
\hline & - & coinmodities mainly dealt with & A & B & C & D \\
\hline & $\begin{array}{l}\text { W.S. } \\
\text { "" } \\
\text { ", }\end{array}$ & $\begin{array}{l}\text { automobiles } \\
\text { chemicals, drugs, cosmetics } \\
\text { instruments for tele-communication, } \\
\text { doutestic electric instruments }\end{array}$ & $\begin{array}{l}12 \\
46 \\
17\end{array}$ & $\begin{array}{r}100 \\
87 \\
82\end{array}$ & $\begin{array}{r}100 \\
98 \\
94\end{array}$ & $\begin{array}{r}100 \\
89 \\
87\end{array}$ \\
\hline & " & $\begin{array}{l}\text { furniture, fittings, household-utensils } \\
\text { selling-offices of mining or } \\
\text { manufacture enterprises }\end{array}$ & $\begin{array}{l}45 \\
39\end{array}$ & $\begin{array}{l}93 \\
72\end{array}$ & $\begin{array}{l}95 \\
92\end{array}$ & $\begin{array}{l}98 \\
78\end{array}$ \\
\hline & & $\begin{array}{l}\text { stores of uniform rate system } \\
\text { department-stores having less than } 50 \\
\text { employees }\end{array}$ & $\begin{array}{l}1 \\
3\end{array}$ & $\begin{array}{l}100 \\
100\end{array}$ & $\begin{array}{l}100 \\
100\end{array}$ & $\begin{array}{l}100 \\
100\end{array}$ \\
\hline 呑 & & $\begin{array}{l}\text { automobiles } \\
\text { gasoline or petroleum } \\
\text { flowers and plants } \\
\text { furs (coats, etc.) } \\
\text { cameras } \\
\text { musical instruments } \\
\text { sporting goods and others for recreation } \\
\text { ready-rnade European clothes } \\
\text { lacquer wares } \\
\text { dishes prepared } \\
\text { chickens and eggs } \\
\text { domestic máchines (sewing machines, etc.) }\end{array}$ & $\begin{array}{r}6 \\
26 \\
43 \\
3 \\
7 \\
11 \\
29 \\
23 \\
19 \\
17 \\
11 \\
43\end{array}$ & $\begin{array}{r}100 \\
65 \\
81 \\
0 \\
100 \\
89 \\
76 \\
57 \\
66 \\
65 \\
89 \\
67\end{array}$ & $\begin{array}{r}100 \\
96 \\
100 \\
100 \\
100 \\
100 \\
100 \\
96 \\
95 \\
100 \\
100 \\
98\end{array}$ & $\begin{array}{r}100 \\
69 \\
81 \\
0 \\
100 \\
91 \\
76 \\
59 \\
68 \\
65 \\
91 \\
69\end{array}$ \\
\hline$\stackrel{\Xi}{\Xi}$ & & $\begin{array}{l}\text { clothes for ladies and children } \\
\text { gathering of agricultural products } \\
\text { bread }\end{array}$ & $\begin{array}{r}18 \\
4 \\
12\end{array}$ & $\begin{array}{l}33 \\
75 \\
58\end{array}$ & $\begin{array}{l}78 \\
75 \\
83\end{array}$ & $\begin{array}{r}43 \\
100 \\
70\end{array}$ \\
\hline 㤩 & $\begin{array}{c}\text { W.S. } \\
\text { "I } \\
\prime \prime \\
\text {. }\end{array}$ & $\begin{array}{l}\text { machines, metallic instruments, hard ware } \\
\text { clothing and other personal furnishing } \\
\text { food stuff and drinking } \\
\text { agricultural and aquatic products } \\
\text { works of fine arts, name-cards, etc. } \\
\text { books and magazines } \\
\text { shoes and boots (leather made) } \\
\text { electric instruments (radio, etc.) } \\
\text { second-hand articles in general } \\
\text { butcher's meat }\end{array}$ & $\begin{array}{r}73 \\
149 \\
173 \\
126 \\
289 \\
121 \\
96 \\
221 \\
126 \\
182\end{array}$ & $\begin{array}{l}90 \\
75 \\
61 \\
68 \\
64 \\
55 \\
57 \\
62 \\
66 \\
49\end{array}$ & $\begin{array}{r}100 \\
93 \\
92 \\
91 \\
97 \\
94 \\
91 \\
88 \\
92 \\
92\end{array}$ & $\begin{array}{l}90 \\
80 \\
66 \\
75 \\
71 \\
59 \\
62 \\
71 \\
73 \\
61\end{array}$ \\
\hline$\stackrel{\pi}{\exists}$ & & $\begin{array}{l}\text { time-pieces } \\
\text { eye-glasses } \\
\text { order-made European clothes } \\
\text { drugs \& cosmetics } \\
\text { clothing } \\
\text { Stationery } \\
\text { clothes } \\
\text { second-hand clothing } \\
\text { toys } \\
\text { foreign and small wares } \\
\text { foot-wear } \\
\text { hard wares } \\
\text { kitchen wares } \\
\text { teas } \\
\text { milk } \\
\text { groceries } \\
\text { fruits. } \\
\text { furni ture } \\
\text { house furnishing } \\
\text { Tatami (Japanese floor inat) } \\
\text { fuel } \\
\text { chinas, glass } \\
\text { agricultural instruments } \\
\text { wagon, Trailer } \\
\text { tavern \& restaurant }\end{array}$ & $\begin{array}{r}223 \\
150 \\
345 \\
58 \\
152 \\
-545 \\
456 \\
222 \\
-587 \\
-577 \\
269 \\
-554 \\
80 \\
57 \\
223 \\
361 \\
491 \\
120 \\
215 \\
294 \\
116 \\
206 \\
61 \\
-1224\end{array}$ & $\begin{array}{r}40 \\
45 \\
51 \\
59 \\
54 \\
42 \\
40 \\
-34 \\
39 \\
38 \\
43 \\
36 \\
53 \\
39 \\
47 \\
60 \\
-34 \\
-24 \\
37 \\
51 \\
51 \\
35 \\
-30 \\
58\end{array}$ & $\begin{array}{r}86 \\
\\
91 \\
82 \\
84 \\
74 \\
74 \\
74 \\
71 \\
-69 \\
72 \\
80 \\
-69 \\
92 \\
86 \\
72 \\
94 \\
70 \\
73 \\
70 \\
82 \\
86 \\
72 \\
74 \\
87\end{array}$ & $\begin{array}{r}46 \\
62 \\
62 \\
69 \\
73 \\
56 \\
55 \\
-48 \\
57 \\
53 \\
54 \\
52 \\
57 \\
-45 \\
66 \\
64 \\
-48 \\
-33 \\
52 \\
63 \\
59 \\
-49 \\
-40 \\
66\end{array}$ \\
\hline$\mapsto$ & & $\begin{array}{l}\text { commission merchant } \& \text { broker } \\
\text { bicycle } \\
\text { fresh fish } \\
\text { green grocery } \\
\text { Sake \& condiments } \\
\text { candy \& cake } \\
\text { other groceries } \\
\text { grocery in general } \\
\text { tobacco }\end{array}$ & $\begin{array}{r}-519 \\
212 \\
-1056 \\
-948 \\
-1104 \\
-2888 \\
295 \\
-598 \\
-904\end{array}$ & $\begin{array}{l}-14 \\
-37 \\
-22 \\
-31 \\
-24 \\
-32 \\
-28 \\
-22 \\
-16\end{array}$ & $\begin{array}{l}-39 \\
-55 \\
-50 \\
-63 \\
-44 \\
-68 \\
-60 \\
-40 \\
-35\end{array}$ & $\begin{array}{r}-36 \\
67 \\
-40 \\
-49 \\
54 \\
56 \\
-46 \\
54 \\
-47\end{array}$ \\
\hline
\end{tabular}


Table II

\begin{tabular}{|c|c|c|c|c|c|c|}
\hline & & A B & & & A & B \\
\hline retail & match \& tobacco & I I & $n$ & neck-tie or ribbon & $" \prime$ & $\prime \prime$ \\
\hline$\prime \prime$ & Japanese condiments & $" \prime \prime$ & " & Japanees umbrella & $" \prime$ & $n$ \\
\hline$" 1$ & European condiments & $" \prime \prime$ & " & furniture & $\prime \prime$ & $\prime \prime$ \\
\hline " & cooking oil & $" \pi$ & $\prime \prime$ & radio and others & $\prime \prime$ & $" \prime$ \\
\hline$\prime \prime$ & groceries & " " & " & medicines & $"$ & $\prime \prime$ \\
\hline " & tinned goods $\&$ refreshers & $" \prime$ & $" 1$ & hard wares & $\prime \prime$ & " \\
\hline " & fruits and green groceries & $" \prime \prime$ & repair & farm machines & " & " \\
\hline " & tea & $\prime \prime$ & $\prime \prime$ & watch or clock & $\prime \prime$ & $\prime \prime$ \\
\hline$\prime \prime$ & Sake (Japanese wine) & $" 1$ & service & sergical medichine & $" \prime$ & " \\
\hline " & cotton yarn $\&$ sewing needle & $" 1$ & " & dental medichine & " & $\prime \prime$ \\
\hline$" \prime$ & note book, pencil \& others & " & " & sewer of ordinal wears & $" \prime$ & " \\
\hline$\prime \prime$ & farm chemicals & " , & $"$ & beauty-parlors & $" \prime$ & $\prime \prime$ \\
\hline service & internal medicines & $" \prime$ & $" \prime$ & cinema & $"$ & $" \prime$ \\
\hline$" \prime$ & barber & " & retail & ready made wear & III & $" \prime$ \\
\hline retail & fresh fish & II, & " & woollen yarn & $\prime \prime$ & $\prime \prime$ \\
\hline$" 1$ & foot wears & 11 & $n$ & rubber water proof & " & " \\
\hline " & jap boots & $" 1$ & " & umbrella & $" 1$ & $" \prime$ \\
\hline$\prime \prime$ & bicycle & 11 & $" \prime$ & shoes & $"$ & $" \prime$ \\
\hline " & farm instruments & $\prime \prime$ & $\prime \prime$ & gasses & $\prime \prime$ & $\prime \prime$ \\
\hline repair & $\prime \prime$ & $\prime \prime$ & $n$ & books & $\prime \prime$ & " \\
\hline " & radio $\&$ electric instruments & $"$ & $"$ & horse èquipment & $" \prime$ & $"$ \\
\hline service & pediatry medicines & $" 1$ & " & farm machines & $" \prime$ & $\prime \prime$ \\
\hline retail & meat & 1, & " & wagon & $"$ & $" \prime$ \\
\hline$\prime \prime$ & clothes & $"$ lI & service & ophthalmic medicine & $\prime \prime$ & $" \prime$ \\
\hline$" 1$ & under shirts & $" \prime$ & $\prime \prime$ & photo studio & $" 1$ & $"$ \\
\hline
\end{tabular}

Table I A : Total number of shops of each kind (in whole Yamagata Pref.)

B : Number of shops in cities (\%)

C : Number of shops in cities and towns (\%)

$($ W.S. $=$ whole Sale $)$

D : Percentage of shops of cities in total of cities and towns

Table II A ; Inawashiro Basin B ; Shinjo Basin

and "that of towns", for the rarity agrees to the percentage of shops in cities out of those in cities and towns in general. (By the nature of dotting, the spaces between the simbols and the dots in Fig. 4 is the percentage of those in towns.) Again, the sub-classification has been tried by $90 \%$ in cities and towns, and the value of $90 \%$ is a discontinuous line of rnumber in cities/that in cities and towns $\rfloor$ above which the convergence of shops into cities is very peculiar. Table I is the synopsis of the results of classification in this procedure. They are observed to have some similar tendency to the classified articles in Table II, which were obtained in the field survey of buying habits in another basin in 
the Tohoku Region. ${ }^{(6)}$

\section{The Service Pattern in the Shinjo Basin}

Set two town-communities apart, the 15 mura in the basin are quite different from one another in size, population and service-capacity, and their subdivisions of inner communities are also not common. Therefore, the maps of social divisions and centres according to the number of shops were made (Fig. 4-A,B). The major settling type in the basin is the agglomerated settlements of 20 to 40 houses $(150-300$

pop.) which form a fundamental community in Japan ("Buraku" in Japanese). But surch a smallest unit is not the community to promote the formation of the centre under consideration here, and, further, some foreign modes of life (such as churches and clubs) have no fundamental power as a social band in

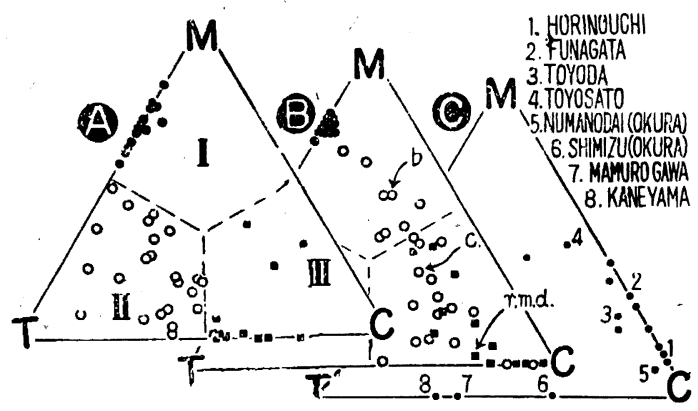

Fig.4 A.B. Classification of services by village to village quetionaire-interview

A: Inawashiro basin B: Shinjo basin

C. Average indices of dependence of communities Japan. Therefore 5 elements-elementary schools, secondary schools, farm associations, younger associations, and women's associations-are chosen to indicate social unities. In the figure, on account of the complicated arrangement of various topographies-hills, fans, table-lands, flood-plains river-terraces, etc.-the social boundaries are often seen to extend over several mura. The chief rivers such as $\mathrm{R}$. Sake, R. Mogami, etc. pla ythe same role as the dividers. The clearest boundary of them is the one found between the bottom of the basin and the mountainous district around, the mode of living on one side being quite different from the other. Furthermore, even in an area of similar physical

(6) Yoshio Watanabe : The Rural Services in the Inawashiro Basin, Fukushima Pref. Ánn. Tôhoku Geogr. Assoc., Vol. 6, No. 1. pp. 56-60 (in Japanese)

The report is based on the results got in the village-to-village survey of the rural buying habits (usual and occasional). Centres are classified into cities, "Yakuba" settlements having more than 30 shops, and others. Everytime when the inhabitants of a mura usually depends for a commodity upon a centre, 1 mark was given to the centre, and 0.5 was given whenever it depends occasionaly. The percentage of the sum of the marks given to the three centres is plotted in the triangular co-ordinate. (Fig.4-A) 
environments, the communities are often divided. within one mura, bounded by, 4-5 elements and having the worthy centre of their cwn. (Funagata and Yamuki show such cases and Nozoki is almost the same type.) In such a case, they are apt to repel and have a quarrel with one another at every event in mura, and the writer call them "Oaza community" temporarily in this report. As a whole, the sub-division of minor communities in a mura is a characteristic tendency this basin shows (Fig. 5-G,F).

Regarding as the commodities which represent the comsumption of the lowest order in the rural district (food-stuff, tobacco and other I-I-I of Table I and II), the centres of every grade as well as the isolated one or two shops scattered widely in the basin (72 group ; 96 shops) play the role with Buraku as their basis, making it possible for the inhabitants to purchase them within $1 \mathrm{~km}$ distance at the remotest. The commodities of higher order served in a mura (bicycles and fish, etc. I-II-I and others) are mostly supplied at the centres which have more than 10 shops and are arranged in an area at a distance of about $8 \mathrm{~km}$ from Shinjo (Fig. 5-B). These centres consist of the most of "Yakuba"(village-office or town-office) settlements and three "Oaza" centres, all of which developed with the groups of agricultural settlements on the flood-plains or terraces of the rivers, Sake, Mogami and Oguni as their hinterland. An example of bicycles (I-II-I) is shown in Fig.' 5-C,' and this indicates the characteristics of this group which are caused by the restriction of distance (by amendment in the case "of bicycles). The group of "Yakuba" settlements take part in the service of the commodities of higher order such as those usually supplied by "shops of towns". The example is given in the buying habits of drapery (IIb-II-III) drawn in Fig. 5-D. In this figure, there appears a sub-area (ocpasional service) formed around these "Yakuba" settlements, and it is a matter of note that the communities in the peripheral mountainous zone do not depend upon the Yakuba settlements inside them, but upon Shinjo and partly upon hawkers as well. This relation is also observed in Fig. 4-C, in which the average values of all commodities are drawn indicating which place the inhabitants of communities depend on. (The value is expressed in the form of percentage got in the similar way as-A, $-\mathrm{B}$, and the plots indicate the manner of all the communities which include the Yakuba settlements as well as some other communities. See the relation of Toyosato and Toyoda; Funagata and Horinouchi; and Shimizu and Numanodai in Okura). In the case of European clothes, a commoditiy of much higher order (IIa-III-III) (Fig. 5-E), a similar pattern remains. On the other hand, two towns in the northern part are worthy of note. They seldom serve other mura and their chief role is to serve the 


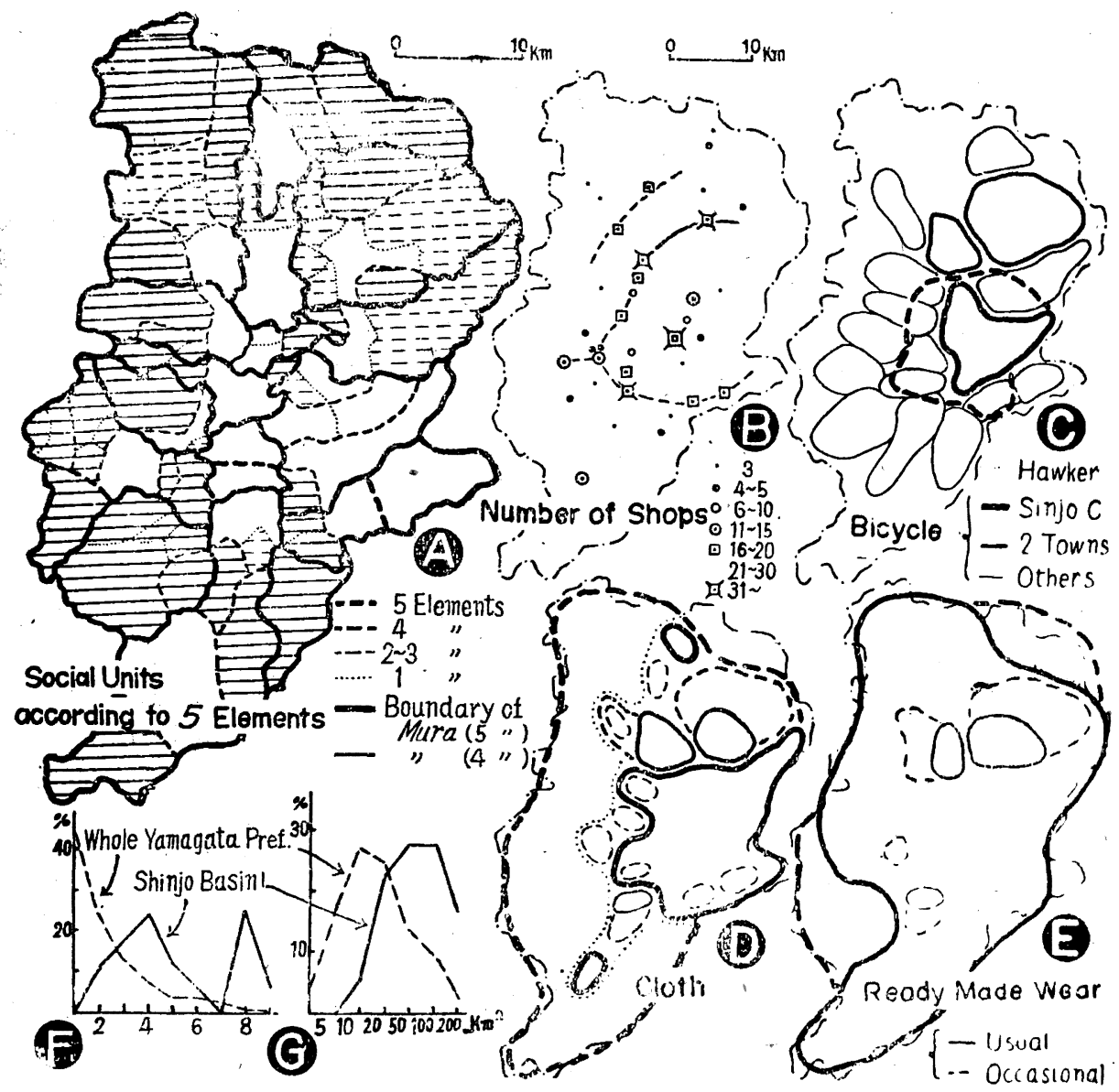

Fig.5 A. Social units (shadowed parts indicate the communities having no centre of more than 6 shops)

B. Pattern of shopping centres

C-E. Examples of buying habits (See also Fig. 4)

F. frequency figure of number of elementary schools in mura

G. frequency figure of size of mura

communities within their political boundary. It is not of a common character with ordinary towns in Japan but a character to be ranked in service-hierarchy with mura, though they are machi administratively. Such a relation is shown in Fig. 4-C. As a result, the whole basin is overwhelmingly influenced by Shinjo City as the influence of the towns is very weak (Fig. 4-B). 


\section{The Role and the Service Capacity of Mura, Towns and a City of the Shinjo Basin}

The shopping pattern above stated, indicates the structure of a concentric circle also in the Shinjo Basin. The Yakuba settlements and the two towns of this basin can be replaced by the towns of the others, and the small community centres by mura, though such replacement is not an accurate way to compare the two, for the other basins cited in Fig. 1 probably have, outside the smallest dots, one more zone which corresponds to the mountainous zone of small comunity centres of the Shinjo Basin.

The young and steep mountain ranges in Japan has controlled a service pattern so strongly, and, consequntly, in the case of basins having such concentric arrangements the range of service-favourity differs greatly in area because it is closely related to whether centres of a high class appear around the major centre or not. (The case of Shinjo Basin may be an extreme one just before the formation of a town zone). Taking occasion,the author adds that in the proportion of the area to the number of the cities, towns and mura of whole Yamagata Pref. this basin must contain 33 of mura which are in number near the communities divided by the overlapping lines of more than 2 or 3 elements, and it must also contain 5.5 machi, one third of mura (including two outstanding towns), and one city. And as compared with a similar survey in Yamaguchi Pref! in the southwestern part of Honshu, ${ }^{(6)}$ a unit area of this basin seems to contain social institutions as well as retail services of one-step-lower-order than that place.

The A-C of Fig. 5 are the results of some calculations concerning cities, towns and mura respectively, the commercial groups classified in Fig. 3 being made use of. And the D-E show the indices got when the results of the calculation of each kind are respectively compared with the mean value of the prefecture. (The writer tried another comparison with the mean value obtained excluding Yamagata City and its hinterland, Murayama district, lest Yamagata City, the site of the Prefectural office, should bring a peculiar influence. But the results were almost alike contrary to his anxiety). Regarding as mura,the number of the shops per mura is, in all the groups but III, large in the mura of the Mogami Basin. This is because the areas and the population of mura become larger than ordinary ones due to the low population density. Concerning the number of the shops per population as well, (service-density, this means the degree of being favoured by the service when seen from the side

(6) Tadahiro Ovo: Structure of Life Region in Suô District, The Human Geography, July. 1951. pp.40-49 (in Japanese) 


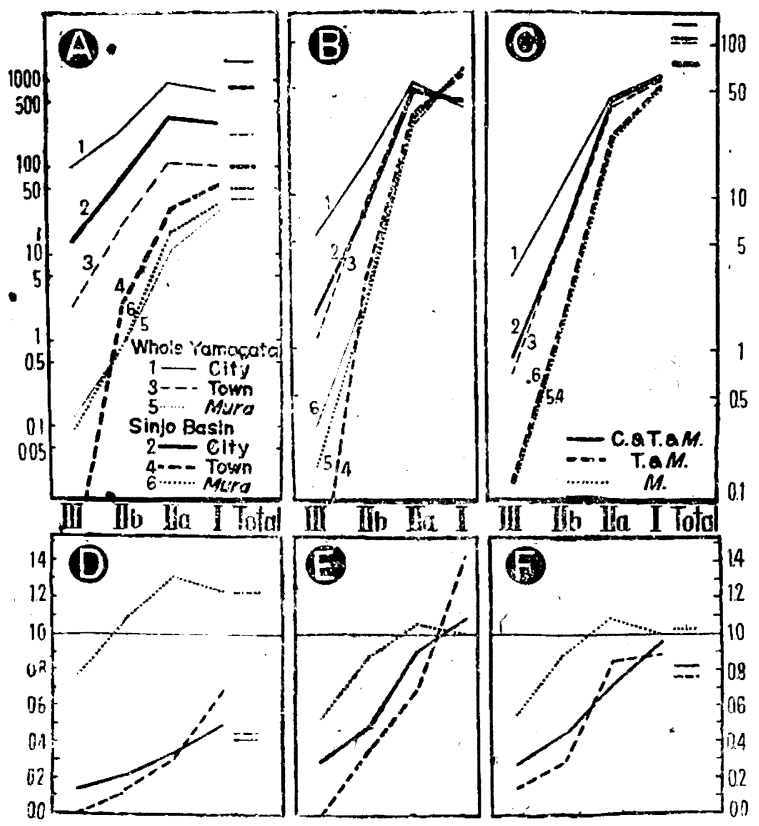

Fig.6 Commerce of cities, towns and mura (Shinjo basin and whole Yamagata Pref. : on census data)

$A$ : number of shops per city, town or mura

B : composing rate of each group

C : number of shops in centre per population (centre and its hinterland)

-.number of shops in cities (or towns, or mura) per pop. of cities, towns $\&$ mura (or towns $\&$ mura, or mura)

D-F ; comparative value with mean of prefecture (same category as above posed figure) of consumers) it is below the standard especially in groups of higher order, but is clearly above it in the group of IIb which is the lower order of the "shops of towns". The two towns are far below the standard level of the towns in Yamagata Pref. and rather to be ranked with mura with regard to their scales. Further, in the commercial component, they completely, show the types of mura, revealing the foundation of development. The inferiority of town services weighs more heavily on Shinjo City. But it does not attain to the general level of cities, and its commercial component and its service-density cleary show the characters towns possess. As the result

of the above features, it can be said that the total number ofthe shops per total population of the basin as the service density of a nodal region cleary goes down in a straight-line towards the service of a higher order.

\section{The Population Density and Services}

From above, it is clarified that the pattern of the Shinjo Basin also shows a typical arrangement of a concentric circle-structure but its service density is much lower especially in the higher order. The population distant from a centre takes a less proficient role in expenditure of the commodities supplied by the centre (Zentralen Guter $=$ Z.G.) than the one near the centre. Accordingly, an area of a low population density, especially in the case of a 
district in which a lower ratio of population is shown in a centre itself, must show less expenditure of $Z$. G. This was proposed by Christaller, who, in addition, recognized a minimum hinterland (Untere Grenze der Reichweite $=$ U. G.) on which the enterprise of each commerce can be maintainèd ${ }^{(7)}$ The latter is expressed by means of distance, but in practice means a population combined with distance. Starting from these prirciples, the writer intends here to consider the relation between the population density and the commercial service density of an area, not the development of "Zentralität" or the distribution of the centres of each order.

Now, let the author consider a dense population like $P$ in Fig. 7. In this case, the articles of all orders will be supplied and purchased without, any restriction of distance. Next, this population is supposed to be spatially scattered and uniformly in all parts of the area. Then the supply by any centre

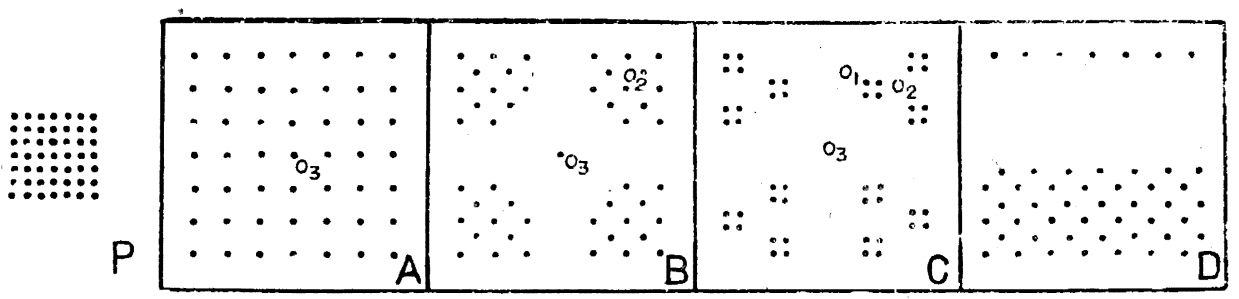

Fig.7 The scheme of dispersed population

and of any article can not be free from the influence of this dispersion of population. (A main centre in the middle part will probably become more powerful as compared with minor ones, and the service density of the area will grow lower in all the varieties. But a population, in reality, is scarcely distributed in such an arithmetically homogeneous manner, a concentration like $B$ or others is apt to appear. In the case of $B$, the service of $\mathrm{O}_{1}$ concerning the goods with U.G. of more than $\frac{P}{4}$ is not essentially different from that of $\mathrm{A}$. But the service of $\mathrm{O}_{2}$ with regard to the commodities with the U. G. of less than $\frac{P}{4}$ is far profitable as compared to the service of those at any centre in $\mathrm{A}$. (The profitability is middle between $\mathrm{P}$ and $\mathrm{A}$ ). Furthermore, any of the four concentrated groups $\left(\frac{P}{4}\right)$ in $B$ is divided again into three local agglomerations of $\frac{P}{4 \times 3}$ (Fig. C), then the service of Z.G. of more than $\frac{P}{4 \times 3}$ at any centre in $C$ is essentially same as that in $B$, and that concerning to $Z$. G. of more than $\frac{P}{4}$ is same as the case of $A$ or $B$, but the supply of $0_{3}$ concerning

(7) W. Christaller : opp. cit., S.33-38, S.54-63 
the commodities with the U. G. of less than $\frac{P}{4 \times 3}$ is nore profitable than the service of those commodities by any centres in $B$ (of cause than in $A$; as profitable as $\mathrm{P}$ in the case of $\mathrm{C}$ ). Even with regard to a deformed concentration like $\mathrm{D}$, it is obvious that the articles with the U. G. of less than $\frac{P}{7}$ bring more gain than A. From above it may be said that a thin population density has greater influence on the articles of larger U. G. than on those of smaller U. G. so far as unevenness is seen in the distritution of population.

As the classification of the articles adopted in (Fig. 4) is based upon the state of their distribution and is correlated to rarity, it must also be defined at the same time as the classification of U. G. Therefore the above considerations may contribute to the interpretation of the aspect that the Shinjo Basin assumes. The low population density caused by the dispersion of the agglomerated villages of 20 to 40 houses is observed to have had a scarce influence upon the service of lower order. And the dense population on the flood-plains and terraces of the Rivers Mogami, Sake and Oguni urged the development of the "Yakuba" settlents which supply the commodities of lower-middle order successfully, but nevertheless; it has not a foundation enough to produce machi groups any more. And some of the higher service varieties are brought into mura, and Shinjo City, a great powerful centre, has come to be, a great dominating-centre. And, as the results, the service-density of the wholę area falls down in a strait line towards the service of high order. These characters are essentially same as what is shown in the scheme.

Furthermore, let the author consider the above mentioned fact that in the Shinjo Basin, Shinjo City contains the commercial structure of a town and the two towns those of mura. A centre usually shows so compact accumulation of the population that the Z.G. of a smaller U.G. is maintained by the population of the centre itself. If the population of the centre gradually approaches, in number, that of the hinterland (including its centre) the centre of the next order generally demands, the services are very profitable so far as they are concernd to the commodities having U.G. lower than such population. And only the ones having larger U.G, (the varieties which ought to be a real represntative of the centre) is influenced by a low population density. As the correlation of the centres to that of the hinterland has not been generalized yet, $^{(8)}$ the generalization about this movement is of course impossible, but the

(8) About the centers of lower order, some cases are known, showing the mean ratio of from one to one to one to more than two. F.H.Green : Urban Hinterland in England and Wales, Geogr. Jour., Sept. 1950, pp. 64-88. Green : Some Relation between Country and Town in Scotland, Scot. Geogr. Magaz., Apr. 1952, pp. 2-12. J.E.Brush: opp.cit. But they are probably inapropriate for large ones. 


\begin{tabular}{|c|c|c|c|c|c|}
\hline & & IIIab & II & IIb & I \\
\hline \multirow[t]{2}{*}{ A } & \multirow[t]{2}{*}{$\begin{array}{l}a \\
b \\
c\end{array}$} & \multirow{2}{*}{$\begin{array}{r}189.2 \\
78.0 \\
271.5 \text { (city) }\end{array}$} & $\begin{array}{r}10.8 \\
9.5\end{array}$ & $\begin{array}{l}8.0 \\
4.6\end{array}$ & \multirow{2}{*}{$\begin{array}{l}2.4 \\
1.5 \\
4.1 \text { (Mura) }\end{array}$} \\
\hline & & & & 35.5 (town) & \\
\hline \multicolumn{2}{|l|}{ B } & & \multicolumn{2}{|r|}{19.0 (city) } & $2.2-2.6$ (town) \\
\hline
\end{tabular}

Table III A. estimated "Untere Grenze" (thousands)

a : population per shop of each kind (averaged value in each group)

$\mathrm{b}$ : (population per shop of each group) $\times$ (number of shop variety of each group)

c : estimated population of hinterland (including centre)

city: sum popuiation of cities, towns and mura/number of cities town: sum population of towns and inura/number of towns

B. population of urban centre (compact urban area only) in Shinjo Basin

comparison between the values given in Table II and the populations of such centres as Shinjo City (35,000 pop.) kaneyama-machi (2,600 pop.) and Mamurogawa-machi (1,900 pop.) suggests that such a case may occur in the Shinjo Basin.

Based on the purely mechanical consideration of population-just as Christaller did-the author has attempted to give some interpretations to the Shinjo Basin. But it goes without saying that nature is an accumulation of innumerable elements. He never thinks at all that this mechanical conclusion gives a complete explanation of the basin, but presents a standpoint from which a greater part of the characteristics of the basin could be understood. Moreover, he has one thing to add here. Christaller-the author as well-disregarded the trades having subsidiary works. In a less populated area the increase of them is theoretically expected to unite the demand for the better management of merchants with that for the facility of consumers. Nevertheless, the ratio of subsidiary occupation the Shinjo Basin exhibits (17.8\% in mura and towns and $27.5 \%$ including cities) is lower than that of the whole prefecture (45.4\% and $29.3 \%$ ), though the total realized by a year's sale per shop is lower than that of the prefecture. A further study will be necessary to solve this problem in future. 